\title{
Leptomeningeal disease: current diagnostic and therapeutic strategies
}

\author{
Gautam Nayar ${ }^{1,2,3}$, Tiffany Ejikeme ${ }^{1,2,3}$, Pakawat Chongsathidkiet ${ }^{1,2,6}$, Aladine A. \\ Elsamadicy ${ }^{1,2,3}$, Kimberly L. Blackwell ${ }^{4}$, Jeffrey M. Clarke ${ }^{5}$, Shivanand P. Lad ${ }^{3}$ and \\ Peter E. Feccili,2,3,6 \\ ${ }^{1}$ Duke Brain Tumor Immunotherapy Program, Department of Neurosurgery, Duke University Medical Center, Durham, NC, USA \\ ${ }^{2}$ The Preston Robert Tisch Brain Tumor Center, Duke University Medical Center, Durham, NC, USA \\ ${ }^{3}$ Department of Neurosurgery, Duke University Medical Center, Durham, NC, USA \\ ${ }^{4}$ Department of Radiation Oncology, Duke University Medical Center, Durham, NC, USA \\ ${ }^{5}$ Division of Medical Oncology, Duke University Medical Center, Durham, NC, USA \\ ${ }^{6}$ Department of Pathology, Duke University Medical Center, Durham, NC, USA
}

Correspondence to: Peter E. Fecci, email: Peter.fecci@duke.edu

Keywords: leptomeningeal disease, neoplastic meningitis, leptomeningeal carcinomatosis, intrathecal chemotherapy, radiation therapy

Received: May 10, $2017 \quad$ Accepted: July 20, $2017 \quad$ Published: August 16, 2017

Copyright: Nayar et al. This is an open-access article distributed under the terms of the Creative Commons Attribution License 3.0 (CC BY 3.0), which permits unrestricted use, distribution, and reproduction in any medium, provided the original author and source are credited.

\section{ABSTRACT}

Leptomeningeal disease has become increasingly prevalent as novel therapeutic interventions extend the survival of cancer patients. Although a majority of leptomeningeal spread occurs secondary to breast cancer, lung cancer, and melanoma, a wide variety of malignancies have been reported as primary sources. Symptoms on presentation are equally diverse, often involving a combination of neurological deficits with the possibility of obstructive hydrocephalus. Diagnosis is definitively made via cerebrospinal fluid cytology for malignant cells, but neuro-imaging with high quality T1-weighted magnetic resonance imaging can aid diagnosis and localization. While leptomeningeal disease is still a terminal, late-stage complication, a variety of treatment modalities, such as intrathecal chemotherapeutics and radiation therapy, have improved median survival from 4-6 weeks to 3-6 months. Positive prognosticative factors for survival include younger age, high performance scores, and controlled systemic disease. In looking to the future, diagnostics that improve early detection and chemotherapeutics tailored to the primary malignancy will likely be the most significant advances in improving survival.

\section{INTRODUCTION}

Leptomeningeal disease (LMD) is a late-stage complication of systemic cancers caused by multifocal metastases to the leptomeninges, which consist of the pia mater, arachnoid, and subarachnoid space. Common neoplastic etiologies of LMD include breast, lung (mainly non-small-cell lung cancer [NSCLC]), gastro-intestinal, melanoma, primary central nervous system (CNS) cancers (such as medulloblastoma, ependymoma, pineoblastoma, primitive neuroectodermal, or primary CNS lymphoma), lymphoma (mainly non-Hodgkin's Lymphoma [NHL]), leukemia (mainly acute lymphoblastic leukemia [ALL]), and multiple myeloma [1-3].

Despite advances in targeted radiation and chemotherapy, survival remains poor after diagnosis of leptomeningeal involvement, averaging 3-6 months. Survival varies by etiology, with breast cancer patients having the best prognosis $(13-25 \%$ survival at one year and $6 \%$ at two years) $[1,4,5]$. Predictors of longer survival include younger age of diagnosis, a Karnofsky Performance Score (KPS) above 70, long duration of symptoms, controlled systemic disease, lack of encephalopathy or focal neurological deficits on 
examination, low levels of cerebrospinal fluid (CSF) protein, and lack of bulky disease on imaging $[1,6,7]$.

\section{EPIDEMIOLOGY}

In the United States, $1-8 \%$ of cancer patients are diagnosed with LMD, with approximately 110,000 cases of LMD per year in the U.S. [4] LMD is found in $1-5 \%$ of patients with solid tumors, and $1-2 \%$ of patients with primary brain tumors (Table 1). The exact incidence of LMD is difficult to determine, since gross examination at autopsy may overlook signs of LMD, and microscopic pathological inspection may be normal if the seeding is multifocal or if an unaffected area of the CNS is examined. Adenocarcinomas are the most common tumors to metastasize to the leptomeninges. Of the patients with NSCLC, 30-64\% have CNS metastases, of which 4-7\% have LMD $[5,8,9]$.

Incidence and prevalence of LMD are both increasing due to better imaging modalities and improved ability to treat, such as with epidermal growth factor receptor (EGFR) tyrosine kinase inhibitors, anaplastic lymphoma kinase (ALK) inhibitors, and whole brain radiation. EGFR mutations are seen in $10-15 \%$ of Caucasians and $30-40 \%$ of Asian NSCLC cases. ALK gene rearrangements are found in $4-5 \%$ of NSCLC [10]. Overall, $9-25 \%$ of patients with small-cell lung cancers demonstrated LMD. CNS involvement is seen clinically in $30 \%$ of patients with melanoma, and as high as $75 \%$ at autopsy [11]. Although only 5\% of patients with breast cancer develop leptomeningeal involvement, it remains the most common etiology of LMD [12]. The second most common tumor with LMD is lung cancer. Rare neoplasms, such as retinoblastoma and embryonal rhabdomyosarcoma, can also spread to leptomeninges. Occasionally, LMD originating from sarcomas can also be found, although it is uncommon. Medulloblastomas, ependymomas, and gliomas are tumors of intracranial origin that can spread to the CSF and elicit LMD. However, LMD remains rare in high-grade gliomas due to rapid deterioration that precludes leptomeningeal involvement [13]. Squamous cell carcinomas of the head and neck likewise can spread to the leptomeninges along the cranial nerve tracts. Intracranial metastases accompanied LMD in $98 \%$ of patients with a non-leukemic primary cancer [14].

LMD has also become more frequent with as survival has extended for cancer patients [15]. The longer a patient bears his or her primary cancer, the higher the prevalence of LMD, as control of non-CNS cancers may allow for more time for the development of CNS metastases. Additionally, the CNS may be a particular repository for some cancer subtypes and/or treatment exposures. For instance, ALK gene arrangements characterizing a subtype of NSCLC are normally responsive to crizotinib, but patients treated with this agent are frequently found with intracranial metastases at relapse [16]. As such, use of large-molecule antineoplastic agents with limited CNS and CSF penetration may control systemic disease, but leave LMD untreated behind the blood-brain and blood-CSF barrier.

\section{CLINICAL FEATURES}

As malignant cells can spread to any area of the CNS and precipitate symptoms, leptomeningeal disease can have various initial clinical presentations. Common symptoms include cranial nerve deficits, radicular pain, headache, back pain, visual disturbances, diplopia, hearing loss, onset of psychiatric disorders, seizures, or cauda equina syndrome [1, 5, 17-19]. Proposed mechanisms leading to these symptoms include direct compression of parenchyma, parenchymal invasion, ischemia secondary to vessel involvement, metabolic strain, and disruption of the blood-brain barrier [20]. Furthermore, malignant growth can impair flow of CSF in more than half of patients, leading to symptoms of obstructive or communicative hydrocephalus such as nausea, vomiting, somnolence, and positional headaches.

Findings may initially be subtle, such as isolated diplopia or radicular pain, and so are prone to being dismissed in patients who are sick with metastatic disease. However, symptoms progress quickly in severity and evolve along multiple segments of the neuraxis [21]. The development of such neurological symptoms in a patient with known metastatic disease is highly suspicious for leptomeningeal involvement [22]. Nevertheless, it remains important to rule out alternative causes, such as parenchymal disease, chemotherapy or radiation side effects, paraneoplastic syndromes, sarcoidosis, or infectious etiologies [23].

\section{DIAGNOSTICS}

\section{Cerebrospinal fluid}

Presence of malignant cells on CSF cytology provides the gold-standard for diagnosing leptomeningeal carcinomatosis [24]. If location of the disease is suggested by symptomatology, fluid should be drawn from nearby. Otherwise, fluid should be drawn from the lumbar or cisternal regions, as this has shown increased sensitivity and specificity compared to intraventricular fluid [1]. While the first lumbar puncture is only $50-60 \%$ sensitive, a repeat collection increases sensitivity to $80 \%$. Additional lumbar punctures increase the sensitivity by $2-5 \%$ per collection. Each CSF collection should draw 5-10 mL to ensure a sufficient amount for analysis [25].

If malignant cells are not seen, analysis of CSF protein levels can be informative $[1,17]$. Particularly, a protein level above $45 \mathrm{mg} / \mathrm{dL}$ is seen in $63-90 \%$ of patients with leptomeningeal disease. If levels are very high $(>500 \mathrm{mg} / \mathrm{dL}$ ), then there is likely blockage or advanced 
Table 1: Common LMD etiologies

\begin{tabular}{l|l|l|l|}
\hline Primary-Specific Characteristics of LMD & Prognosis & \multicolumn{1}{|l}{ Additional Treatment Modalities } \\
\hline Primary Cancer & $30-75 \%$ & $\begin{array}{l}\text { BRAF inhibitors (Vemurafenib and } \\
\text { Dabrafenib) and Checkpoint inhibitors } \\
\text { (Ipilimumab and Nivolumab) } \\
\text { improved survival (16.9 weeks vs. 2.9 } \\
\text { weeks) in prospective studies }\end{array}$ \\
\hline Melanoma & $5-30 \%$ & Median: 2.6 months & $\begin{array}{l}\text { IT Rituxumab in Phase 1 studies. } \\
\text { Prophylaxis with IT chemotherapy. }\end{array}$ \\
\hline NSCLC & $9-25 \%$ & Median: 3.5 months & $\begin{array}{l}\text { EGFR TKI improved survival if } \\
\text { EGFR+ in multiple case reports }\end{array}$ \\
\hline Breast Cancer & $5 \%$ & $\begin{array}{l}\text { Median: 4.2 months } \\
\text { (longer if hormone } \\
\text { receptor positive) }\end{array}$ & $\begin{array}{l}\text { High-Dose MTX trial } \\
\text { (NCT02422641) pending. IT } \\
\text { Trastuzumab if HER2+. }\end{array}$ \\
\hline
\end{tabular}

disease. Another useful predictor of carcinomatous pathology is high CSF pressure $(>150 \mathrm{~mm})$, seen in $30-57 \%$ of patients. Furthermore, CSF pleocytosis is seen in $33-79 \%$ of patients with leptomeningeal disease, and glucose levels are often decreased $(<60 \mathrm{mg} / \mathrm{dL})$ in $24-62 \%$ of patients [26]. Conversely, a normal CSF profile is seen in less than $5 \%$ of patients with leptomeningeal disease, and is therefore a strong negative predictor.

Methods for CSF analysis specific to the primary malignancy, such as immuno-histochemistry, flow cytometry, fluorescent in-situ hybridization, or polymerase chain reaction, can further improve detection rates [27-29]. Furthermore, CSF analysis for common tumorspecific antigens, such as CA 15-3 or carcinoembryonic antigen (CEA), can be considered if the primary malignancy is known [30-33]. An early study has shown carcinoembryonic antigen to be synthesized intrathecally in $89 \%$ of meningeal carcinomas, but also in $47 \%$ of intraparenchymal carcinomas, which may lead to misdiagnosis [34]. CSF levels of the proangiogenic factor, VEGF, when standardized to serum albumin and VEGF levels, have been shown to produce a relatively sensitive $(83.3 \%)$ and specific $(88.4 \%)$ method of diagnosis for LMD [35]. Adjustment for serum levels is important given that leptomeningeal disease can damage the bloodbrain barrier and so alter diffusion [26]. Given these drawbacks and a lack of quality studies, tumor-specific antigens are currently not included in any standardized diagnostic algorithm. Given the variety of sensitive analytical methods, CSF studies continue to provide the most definitive approach to diagnosis of leptomeningeal disease.

\section{Neuro-radiography}

Abnormalities on imaging can be found in $70-80 \%$ of patients with leptomeningeal disease, although more often in solid versus hematological primary cancers $[1,17,36]$.
The imaging modality of choice is high quality, T1weighted magnetic resonance imaging (MRI) with gadolinium contrast, which has been shown to be more sensitive compared to contrast enhanced CT $[37,38]$. All imaging should include the brain and spine, as leptomeningeal disease can impact the entire neuraxis.

On MRI, the most common finding is pial enhancement and nodularity, typically over the cerebral convexities, in the basal cisterns, on the tentorium, or in the ventricular ependymal surfaces $[26,38]$. Common findings on imaging of the spinal cord include patchy involvement of nerve roots with occasional matting and intradural extramedullary nodules, particularly at the cauda equina [39]. This is particularly important in allowing localization of symptomatic lesions for palliative treatment, such as those causing painful radiculopathy or obstructive hydrocephalus.

Despite advances in imaging techniques and development of novel MRI sequences over the past few decades, early detection of leptomeningeal disease still has not been found to impact overall survival [2]. Furthermore, these findings are fairly non-specific, and could be seen in alternative etiologies such as meningitis or lumbar puncture induced intracranial hypotension [40]. Clinical context remains key, and suspicious findings should prompt further analysis in patients with malignancies.

\section{CSF flow studies}

Obstructed flow of cerebrospinal fluid (CSF) develops in $30-70 \%$ of patients with leptomeningeal carcinomatosis $[1,41]$. Compared to conventional MRI, CSF flow studies that utilize Indium-111 DTPA or Technetium-99m labeled albumin are more sensitive for and can better characterize the location of obstructive hydrocephalus, allowing for palliative intervention with focused radiotherapy [42]. Furthermore, failed therapy for the obstructive lesion is a strong predictor for rapid neurological decline and death $[1,43]$. 
CSF flow studies are used prior to initiation of intrathecal chemotherapy, to assess for regions of poor drug penetration or toxic drug accumulation. However, routine analysis of CSF flow for prognostic evaluation remains a rare practice among clinicians.

\section{Diagnostic approach}

The majority of diagnostic algorithms, including recent criteria developed by the Response Assessment in Neuro-Oncology (RANO) group with expertise in LMD, recommend initial evaluation with a CSF profile, CSF cytology, and high quality, gadolinium enhanced MRI [7, 26, 33]. Positive CSF cytology and radiographic evidence is enough to make the diagnosis. A negative initial evaluation should be followed by at least one additional lumbar puncture. However, it has been estimated that up to $25 \%$ of patients with symptomatic LMD can have negative diagnostic evaluations. It remains controversial whether these patients should be presumptively treated. In rare cases, biopsy of the leptomeninges or brain can provide an accurate diagnosis, especially if the primary malignancy is unknown [17].

\section{BIOLOGICAL BASIS}

\section{Strategies for spread}

The leptomeninges, as a component of the CNS, are more resistant to metastatic disease due to the bloodbrain barrier and the blood-CSF barrier. However, the mechanism by which malignant cells bypass these barriers are largely unknown and may vary between primary malignancies. Understanding this process could lead to the development of novel therapeutics that interfere with these mechanisms [44].

Malignant cell seeding can occur in many ways, including hematogenous spread, venous dissemination, or direct invasion. One possible avenue of entry into the CNS could involve the fenestrated endothelium of the choroid plexus, which allows selective passage of solutes otherwise prohibited by intact barriers and tight junctions [45]. Subsequently, spread after initial leptomeningeal involvement is facilitated by constant CSF flow and regulated by various cytokines and growth factors.

Among these inflammatory cytokines is VEGF, a key participant in tumor angiogenesis and endothelial cell proliferation. Previous studies have shown VEGF to be an important biomarker for malignant cells in the CSF by inducing transendothelial migration in breast cancer cells. Its elevated CSF levels are very sensitive and specific for LMD diagnosis from breast cancer, lung cancer, and melanoma, making VEGF an important drug target [46-48]. For instance, Bevacizumab is a monoclonal antibody directed against VEGF that can be administered systemically for patients with LMD.
Chemokines in the CSF are responsible for regulating proliferation, trafficking, and adhesion of leukocytes. Cells with elevated metastatic potential to the CNS are likely to express the chemokine CXCR4 and its ligand stromal cell-derived factor (SDF)-1. CXCR4/SDF-1 signaling has been shown to induce vascular permeability as well as tumor cell migration and penetration through brain microvascular endothelial cells. Additional chemokines such as CXCR1, CXCR2, and CXCL-8 receptors are often overexpressed in melanoma and promote tumor growth and invasion [49-51].

\section{THERAPY}

\section{Current therapy}

Leptomeningeal disease is difficult to treat, with generally poor outcomes. Primary treatment goals include improvement of patients' neurological deficits and quality of life, while avoiding toxicity. Patient selection factors for treatment include high KPS scores and younger age [1]. While one approach to treatment is shown in Figure 1, a lack of large randomized controlled studies has made the choice of therapy controversial [21]. Common therapeutic approaches include radiation therapy to symptomatic anatomical locations and sites where neuroimaging has revealed lesions, followed by intrathecal chemotherapy [52]. Radiation at the local site of lesion is mainly used to alleviate neurological symptoms, primarily by reducing bulky disease to increase chemotherapeutic perfusion to areas with poor flow. Intrathecal chemotherapy can then reduce tumor cells in the CSF and leptomeningeal deposits, preventing additional seeding $[53,54]$. Systemic chemotherapy can be added to the treatment regimen to further treat primary tumors and prolong survival (Table 2) [52]. For example, in a retrospective study of 30 patients with NSCLC complicated by LMD, Riess et al. found that receiving a systemic regimen containing pemetrexed, bevacizumab, or a tyrosine kinase inhibitor demonstrated a statistically significant decreased hazard of death (hazard ratio [HR], 0.24; $p$-value $=0.007$ ) [55]. In addition to disease management, symptomatic treatments include anxiolytics, antidepressants, pain controls, and anticonvulsants.

\section{Radiation}

Radiation therapy is an important modality for providing palliative relief to patients with symptomatic leptomeningeal disease. Cranio-spinal radiation is typically avoided, as marrow toxicity compromises the patient's ability to undergo future chemotherapeutic regimens. Patients with cerebral involvement typically receive whole brain radiotherapy (WBRT), whereas those with symptomatic spinal lesions are candidates for focal radiotherapy. WBRT is usually planned to involve all 
neural tissue from the retro-orbit to the upper cervical vertebrae. Radiation is usually administered at a dose of 3 Gy for 10 days, but can vary between 20-40 Gy as patients with better prognosis tend to receive more sessions. However, there has not been a documented benefit in survival from WBRT [4, 56-58]. Furthermore, WBRT can cause transient somnolence and cognitive decline. On the other hand, focal radiotherapy is well-proven in providing palliative relief, such as reduction of radiculopathies, bulky disease, or obstructive lesions causing hydrocephalus [59]. Resolution of obstructive lesions also increases penetrance and distribution of intra-thecal chemotherapeutics, and so may precede chemotherapy [58].

\section{Intra-thecal chemotherapy}

Intrathecal administration is the most common method to deliver chemotherapeutic agents in non-nodular and non-bulky LMD, although efficacy compared to systemic administration and choice of regimen are poorly understood due to limited randomized controlled trials [21]. Chemotherapies are usually hydrophilic, and therefore do not penetrate the blood-brain barrier well $(<5 \%)$ [20]. Methotrexate (MTX), cytarabine (Ara-C), and thiotepa are commonly administered intrathecally for LMD. Methotrexate is the most studied agent, with standard therapy consisting of two cycles of 10-15 mg twice weekly for 4-6 weeks, followed by monthly maintenance therapy with 10-15 mg if cytological clearance is achieved [60]. Sustained release formulations may offer increased therapeutic value, as a randomized controlled trial of 61 patients with LMD comparing the efficacy of IT sustained-release cytarabine to methotrexate found similar efficacy but significantly increased time to neurological progression and easier-to-manage administration schedule for sustained-release cytarabine [61, 62].

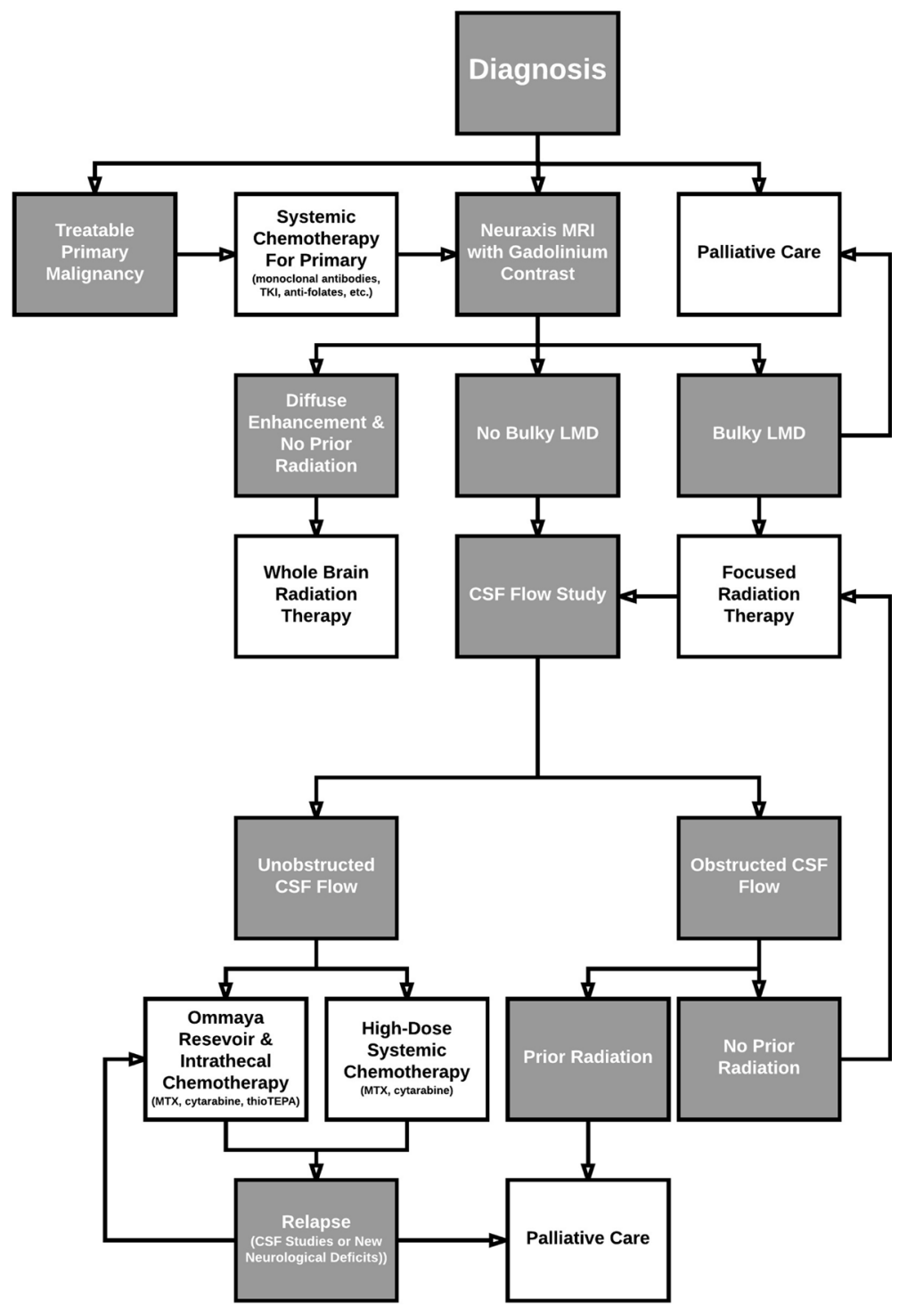

Figure 1: Treatment algorithm. 
Table 2: Clinical trials

\begin{tabular}{|c|c|c|c|c|c|c|c|c|}
\hline Identifier & Acronym & Phase & $\begin{array}{c}\text { Number of } \\
\text { Patients }\end{array}$ & Therapy Class & Therapy Agent & $\begin{array}{c}\text { Dosing } \\
\text { Schedule }\end{array}$ & $\begin{array}{c}\text { Primary }(\mathbf{P}) / \text { Secondary }(\mathrm{S}) \\
\text { Endpoints }\end{array}$ & Results \\
\hline NCT01283516 & ASCEND1 & I & 246 & $\begin{array}{l}\text { Tyrosine Kinase } \\
\text { Inhibitor }\end{array}$ & Ceritinib & $750 \mathrm{mg}$ daily & $\begin{array}{l}\text { P: Dose Limiting Toxicities } \\
\text { (DLT); Overall Response Rate } \\
\text { (ORR); Duration of Response } \\
\text { (DOR) } \\
\text { S: Drug Related Adverse } \\
\text { Events; Absorption and Plasma } \\
\text { Concentration of LDK378 }\end{array}$ & $\begin{array}{c}\text { DLT: } 8 \text { Pts } \\
\text { ORR: } 56.4 \% \text { (All Pts) } \\
\text { Median DOR: } 7.39 \text { mos } \\
\text { (All Pts) } \\
\text { Median PFS: } 18.4 \text { mos - } \\
\text { ALK Pretreated } \\
\text { Most Common AE: } \\
\text { Elevation of AST/ALT } \\
\text { Levels }\end{array}$ \\
\hline NCT01685060 & ASCEND2 & II & 140 & $\begin{array}{l}\text { Tyrosine Kinase } \\
\text { Inhibitor }\end{array}$ & Ceritinib & $750 \mathrm{mg}$ daily & $\begin{array}{c}\text { P: ORR } \\
\text { S: DOR; Disease Control Rate } \\
\text { (DCR); Time to Response } \\
\text { (TTR); Safety Profile; PFS; OS; } \\
\text { Overall Intracranial Response } \\
\text { Rate (OIRR) }\end{array}$ & $\begin{array}{c}\text { ORR: } 38.6 \% \text { (All Pts) } \\
\text { DCR: } 77.1 \% \text { (All Pts) } \\
\text { Median DOR: } 9.7 \text { mos } \\
\text { (All Pts) } \\
\text { Median PFS: } 9.7 \text { mos } \\
\text { (All Pts) } \\
\text { Most Common AE: Nausea, } \\
\text { Diarrhea, Vomiting }\end{array}$ \\
\hline NCT01685138 & ASCEND3 & II & 124 & $\begin{array}{l}\text { Tyrosine Kinase } \\
\text { Inhibitor }\end{array}$ & Ceritinib & $750 \mathrm{mg}$ daily & $\begin{array}{c}\text { P: ORR } \\
\text { S: DOR; Disease Control Rate } \\
\text { (DCR); Time to Response } \\
\text { (TTR); Safety Profile; PFS; OS; } \\
\text { Overall Intracranial Response } \\
\text { Rate (OIRR) }\end{array}$ & $\begin{array}{c}\text { ORR: } 63.7 \% \text { (All Pts) } \\
\text { DCR: } 89.5 \% \text { (All Pts) } \\
\text { Median DOR: } 9.3 \text { mos } \\
\text { (All Pts) } \\
\text { Median PFS: } 11.1 \text { mos } \\
\text { (All Pts) } \\
\text { Most Common AE: } \\
\text { Diarrhea, Nausea, Vomiting }\end{array}$ \\
\hline NCT01828099 & ASCEND4 & III & 376 & $\begin{array}{l}\text { Tyrosine Kinase } \\
\text { Inhibitor }\end{array}$ & Ceritinib & $750 \mathrm{mg}$ daily & $\begin{array}{c}\text { P: PFS } \\
\text { S: OS; ORR; DOR; DCR: TTR }\end{array}$ & $\begin{array}{c}\text { Median PFS: Ceritinib (16.5 } \\
\text { mos) vs Chemo ( } 8.1 \mathrm{mos}) \\
\text { OS: Ceritinib }(29.3 \mathrm{mos}) \mathrm{vs} \\
\text { Chemo }(26.2 \mathrm{mos}) \\
\text { ORR: } 72.5 \% \text { (Ceritinib) } \\
\text { DCR: } 84.7 \% \text { (Ceritinib) } \\
\text { DOR: } 23.9 \text { mos (Ceritinib) } \\
\text { Most Common AE: } \\
\text { Diarrhea, Nausea, Vomiting }\end{array}$ \\
\hline NCT01828112 & ASCEND5 & III & 231 & $\begin{array}{l}\text { Tyrosine Kinase } \\
\text { Inhibitor }\end{array}$ & Ceritinib & $750 \mathrm{mg}$ daily & $\begin{array}{c}\text { P: PFS } \\
\text { S: OS; ORR; DOR; DCR: TTR }\end{array}$ & $\begin{array}{c}\text { Median PFS: Ceritinib (5.4 } \\
\text { mos) vs Chemo (1.6 mos) } \\
\text { ORR: } 39.1 \% \text { (Ceritinib) } \\
\text { DCR: } 76.5 \% \text { (Ceritinib) } \\
\text { Most Common AE: } \\
\text { Diarrhea, Nausea, Vomiting }\end{array}$ \\
\hline NCT02616393 & & II & 60 & $\begin{array}{l}\text { Tyrosine Kinase } \\
\text { Inhibitor }\end{array}$ & Tesevatinib & & $\begin{array}{c}\text { P: Clinical Activity Against BM } \\
\text { and LM } \\
\text { S: Quality of Life Assessments; } \\
\text { PFS; OS }\end{array}$ & \\
\hline & & II & 19 & $\begin{array}{c}\text { Folate } \\
\text { Antimetabolite }\end{array}$ & Temozolomide & $\begin{array}{l}\text { One cycle of } \\
\text { oral TMZ (100 } \\
\mathrm{mg} / \mathrm{m}(2) \text { daily) } \\
\text { one week on } \\
\text { treatment/ } \\
\text { one week off } \\
\text { treatment for } \\
\text { four weeks. }\end{array}$ & & $\begin{array}{c}\text { Study stopped early due } \\
\text { to poor accrual. } 3 \text { of } 19 \\
\text { Pts demonstrated clinical } \\
\text { benefit. }\end{array}$ \\
\hline NCT00424242 & & I & 15 & $\begin{array}{c}\text { Folate } \\
\text { Antimetabolite }\end{array}$ & Pemetrexed & & $\begin{array}{c}\text { P: Correlation of CSF with } \\
\text { Plasma Levels of Different } \\
\text { Doses; Anti-Tumor activity } \\
\text { against LM; Safety Profile; } \\
\text { Assess role of Serum } \\
\text { Biomarkers in Pts with LM }\end{array}$ & \\
\hline NCT01281696 & & $\mathrm{I} / \mathrm{II}$ & 8 & $\begin{array}{l}\text { Monoclonal } \\
\text { Antibody }\end{array}$ & Bevacizumab & $\begin{array}{l}\text { Bevacizumab } \\
\text { (Day 1), } \\
\text { Etoposide } \\
\text { (Days 2-4), } \\
\text { and Cisplatin } \\
\text { on Day } 2 \text { in a } \\
\text { 21-day cycle for } \\
6 \text { cycles. }\end{array}$ & P: CNS Response Rate & $\begin{array}{l}\text { CNS Response Rate: } 60 \% \text { in } \\
5 \text { evaluable pts. } \\
\text { Median OS: } 4.7 \text { mos } \\
\text { Neurologic PFS: } 4.7 \text { mos } \\
\text { Most Common AE: } \\
\text { Neutropenia, Leukopenia, } \\
\text { Hyponatremia }\end{array}$ \\
\hline NCT01325207 & & $\mathrm{I} / \mathrm{II}$ & 34 & $\begin{array}{l}\text { Monoclonal } \\
\text { Antibody }\end{array}$ & Trastuzamab & $\begin{array}{l}10-500 \mathrm{mg} \\
\text { Twice Weekly }\end{array}$ & $\begin{array}{c}\text { P: Safety and maximum } \\
\text { tolerated dose of intrathecal (IT) } \\
\text { Trastuzumab } \\
\text { S: Response to IT Trastuzumab; } \\
\text { CSF Pharmokinetic of IT } \\
\text { Trastuzumab }\end{array}$ & \\
\hline
\end{tabular}


Several case reports have also demonstrated decreased progression and improved prognosis of LMD from breast cancer following intrathecal trastuzumab, a monoclonal antibody that targets malignant cells that overexpress HER2 [63-66].

\section{Surgical interventions}

Surgical interventions include ventriculoperitoneal shunting and placement of intraventricular catheters. Shunting is used in the setting of obstructive hydrocephalus secondary to bulky LMD [20]. Catheter placement allows for the delivery of intra-thecal chemotherapy from a subgaleal reservoir (eg. Ommaya), which increases ease of access while providing more uniform drug distribution and more reliable delivery compared to repeated lumbar administration [17, 33, 67]. However, the complication rate remains high, particularly due to catheter failure and infection. Furthermore, no substantial benefits for survival have been seen with this approach $[1,68]$.

\section{Systemic chemotherapy}

Based on numerous reports, systemic treatments for LMD are believed to increase patient survival. In fact, some authors consider it to be the more vital component to treatment, and thereby exclude intrathecal therapies altogether in patients with responsive cancers. Systemic treatment allows for a significant reduction in toxicity following administration versus intrathecal treatment, while outcomes remain similar $[69,70]$.

\section{Methotrexate}

Methotrexate is an inhibitor or dihydrofolate reductase (DHFR), thymidylate synthetase, and many other NAD(P)H-dependent oxidoreductases (Figure 2). By interfering with the purine synthesis pathway and DNA repair, methotrexate is able to regulate cancer cell metabolism. Methotrexate has a high CSF penetration at high doses. A prospective, nonrandomized study compared the results of bolus intrathecal $(n=15$, two doses per week for 4 weeks) versus high-dose $\left(n=16,8 \mathrm{~g} / \mathrm{m}^{2}\right.$ over 4 hours for 2-4 sessions) systemic methotrexate administration in patients with leptomeningeal disease. High-dose systemic methotrexate ( $8 \mathrm{~g} / \mathrm{m}^{2}$ over 4 hours) showed a higher CSF tumor cell clearance and longer patient survival (13.8 months versus 2.3 months, $P=0.03$ ) compared to bolus intrathecal methotrexate [71].

Though proven to be beneficial at high doses, intracellular metabolism of methotrexate yields an

\section{Methotrexate and Nucleotide Metabolism}

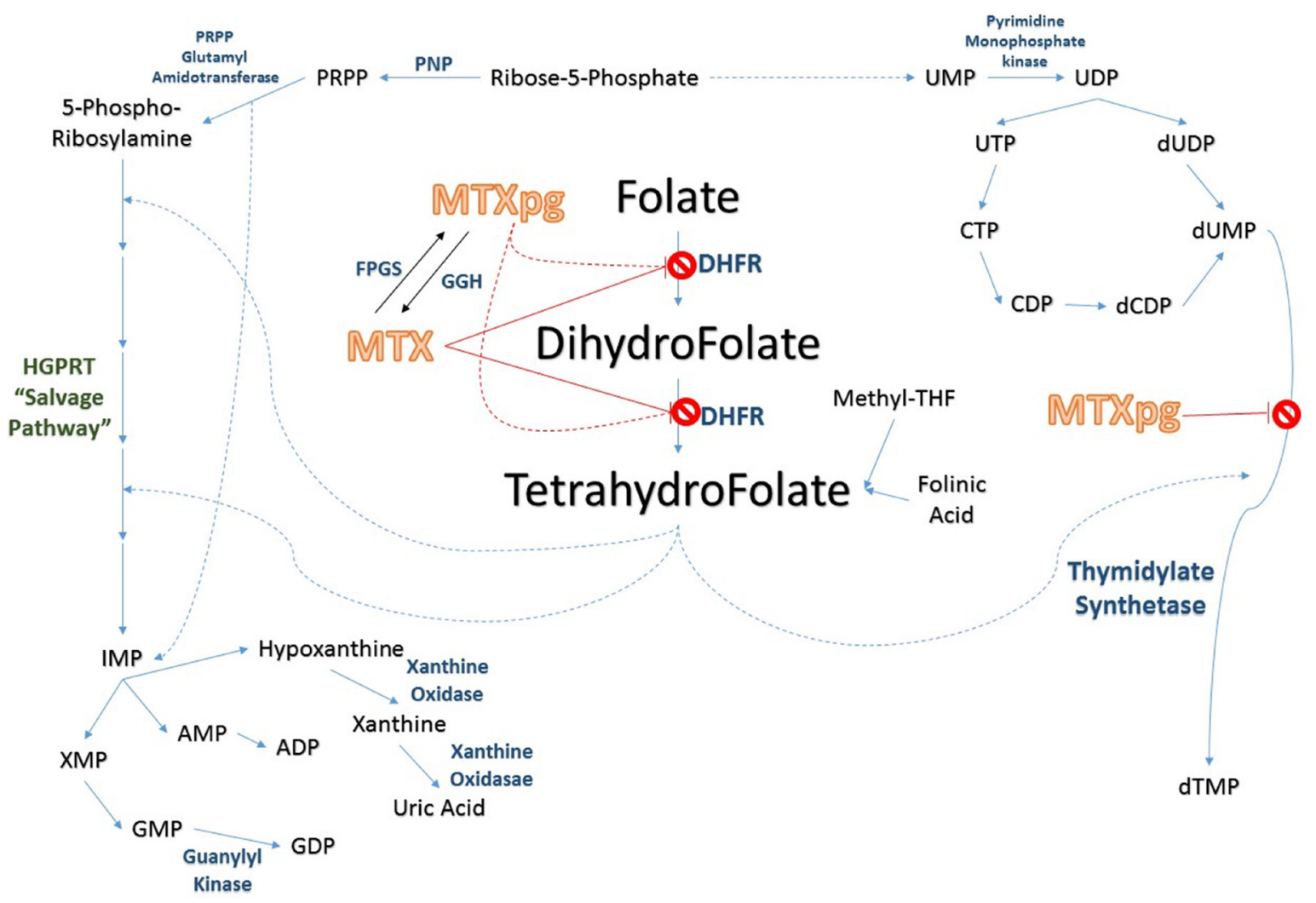

Figure 2: Methotrexate pathway. 
accumulation of its poly-glutamated form, which is known to be a source of toxicity. Leucovorin, also known as folinic acid, is typically given with methotrexate to rescue cells from any adverse effects without affecting the DHFR blockade $[72,73]$.

\section{Capecitabine}

Capecitabine, a chemotherapy whose metabolite can inhibit de novo DNA synthesis, is used to treat gastric, colorectal, and breast cancer [74-76]. While randomized controlled trials are lacking, a retrospective analysis of three patients with refractory LMD originating from breast cancer by Ekenel et al. found that addition of capecitabine provided symptomatic relief and may have improved survival [77]. Another study examining two cases of LMD from breast cancer and one case of LMD from esophageal cancer suggested benefits of oral capecitabine administration [78]. Similarly, a case report documents a patient who had no neurological deficits or symptoms and had her LMD cleared on neuroimaging studies after 3.7 years of oral capecitabine monotherapy following WBRT, although she had persistent periodic presence of malignant cells in her CSF [79]. Further study with randomized control trials is required to understand the efficacy of capecitabine in patients with LMD.

\section{Temozolamide}

Temozolamide (TMZ), a DNA alkylating agent, is an established chemotherapy and the standard of care along with radiotherapy for patients with malignant glioma $[80,81]$. While case reports suggest possible efficacy against LMD secondary to glioma, a randomized control trial of 31 patients by Broniscer et al. showed no impact on outcome [82-86]. Similarly, case reports have suggested efficacy against LMD secondary to paragangliomas [87], adenocarcinomas [88-90], SCLC [91], breast cancer [62], and melanoma [92-94]. However, a phase II randomized controlled trial of 19 patients with LMD from solid tumors was prematurely stopped due to poor accrual, with median time to progression of 28 days (95\% CI: 14-42 days), median survival of 43 days (95\% CI: 28.7-57.3 days), and only two patients finishing the trial [95].

\section{Pemetrexed}

Pemetrexed is a newer generation multi-targeted anti-folate agent, which is approved for the treatment of NSCLC but has been shown to have broader anti-tumor activity. Compared to methotrexate, pemetrexed requires no inpatient hospitalization, has better tolerability, exhibits a more favorable side effect profile, and possesses fewer drug-drug interactions [96]. Furthermore, common toxicities such as myelosuppression and gastro-intestinal disturbances can be predicted prior to therapy through analysis of homocysteine and methyl-malonic acid levels and prevented with vitamin supplementation [97]. As with methotrexate, CNS penetration of the drug is poor, with peak distribution reaching $<5 \%$ of plasma concentrations within one to four hours, and therefore has shown limited efficacy or survival benefit in leptomeningeal disease [96]. Intrathecal administration has not been well explored, with a single animal study finding that intrathecal pemetrexed distributed well and had significant half-life at $1 \mathrm{mg} / \mathrm{kg}$ dosing [98].

One ongoing Phase 1 trial (NCT00424242) exploring intrathecal pemetrexed, being conducted at Northwestern University, is enrolling 15 adult patients with LMD. Escalating dosages of pemetrexed beginning at $500 \mathrm{mg} / \mathrm{m}^{2}$ are administered every 21 days until disease progression. Blood and CSF values are obtained to evaluate drug levels in both compartments. The levels of vascular endothelial growth factor and YKL 40 are assessed as markers of prognosis and response.

\section{Bevacizumab}

Bevacizumab (Avastin) is an anti-VEGF monoclonal antibody commonly used for leptomeningeal enhancement from NSCLC and breast cancer, in which VEGF is significantly elevated and can indicate poor prognosis [46, 48, 99, 100]. Furthermore, recent reports have shown that bevacizumab can improve intra-tumor penetration of other chemotherapeutic agents, such as etoposide and cisplatin in breast cancer [101, 102], carboplatin and paclitaxel in NSCLC [55, 103], and erlotinib in EGFR positive cancers [104], perhaps by normalizing angiogenesis at the tumor site. Bevacizumab, along with temozolamide, has also shown efficacy against leptomeningeal dissemination of recurrent glioblastoma [86]. However, the safety profile of bevacizumab is dependent upon excluding and treating brain metastases due to risk of CNS hemorrhage at the tumor site $[103,105]$. Additionally, initial case series of patients on bevacizumab report minimized radiological evidence of LMD, increased multifocal tumor spread, and dementia secondary to vasculopathy $[106,107]$.

A recent example is a Phase II trial of 39 patients with LMD secondary to breast cancer. Enrolled patients received bevacizumab plus etoposide and cisplatin (BEEP) every three weeks for a maximum of six cycles. The primary endpoints were the clearance of cancer cells in the CSF and improved neurological symptoms. The effect of bevacizumab on etoposide delivery into the CSF was also assessed. The median overall survival of eight enrolled patients was 4.7 months. In five evaluable patients, three exhibited clearance of cancer cells in the CSF. The neurologic progression-free survival was 4.7 months. Hyponatremia, leukopenia, and neutropenia were reported as the most commons adverse events. Bevacizumab did not impact etoposide penetration into 
the CSF, and etoposide concentrations in the CSF were remarkably lower than those in blood [101].

\section{Tyrosine kinase inhibitors}

Tyrosine kinase inhibitors (TKIs) such as erlotinib, gefetinib, and afatinib have proven efficacy in EGFRmutated NSCLC [108, 109]. Initial studies suggest that TKI therapy in such patients who develop LMD might extend survival $[8,110-112]$. CNS penetration of these agents at standard doses has been found to be low, with improved penetration and concentration of gefetinib versus erlotinib [113]. Initial studies of higher dose therapy of erlotinib and gefetinib have shown promising improvements in neurological symptoms, although unacceptable toxicity has been described with 150-200 mg daily erlotinib [114-116]. However, early case series suggest that pulsatile erlotinib at high dosages can achieve increased penetration and efficacy while minimizing toxicity in patients who have progressed on standard TKI therapy [117]. Afatinib, a second generation TKI, has been shown to improve intrathecal penetration, improve survival in patients with CNS metastases, and elicit cerebral response in patients with $\operatorname{LMD}[118,119]$. Initial studies have also shown third generation TKIs, such as osimertinib (AZD9291) and AZD3759, may also be effective in treating TKI-resistant LMD from mutated EGFR lung cancer [120, 121].

Tesevatinib (XL647) is an oral TKI that can cross the blood-brain barrier and deposit in the leptomeninges. In an ongoing multicenter Phase II study (NCT02616393), patients with LMD secondary to EGFR-mutated NSCLC in one arm receive $300 \mathrm{mg}$ of tesevatinib once daily. The primary outcome measure is improvement in clinical activity based on Common Terminology Criteria for Adverse Events (CTCAE v4.03).

Similarly, NSCLC with anaplastic lymphoma kinase (ALK) translocations may be effectively treated by ALK inhibitors such as crizotinib [122, 123]. However, patients with LMD remain poorly treated due to poor CNS penetration and subsequent reseeding of metastases $[16,124,125]$. Initial studies of second generation ALK inhibitors, such as ceretinib and alectinib, have shown increased CNS penetration, decreased radiological burden of metastases and LMD, and improvement in symptoms [126-131].

Ceritinib is currently being studied in multiple Phase II and III studies of LMD secondary to NSCLC with documented ALK rearrangement. Phase II trials include ASCEND-2, which treats crizotinib-resistent LMD, and ASCEND-3, which treats ALK-inhibitor naive LMD. Phase III trials include the ASCEND4 trial, where treatment is randomized to platinum pemetrexed versus ceritinib, and the ASCEND5 trial, where patients failing crizotinib are randomized to pemetrexed, docetaxel, or ceretinib [131]. To date, the ASCEND-2 and ASCEND-3 trial showed improved whole-body overall response rate (ASCEND-2: 38.6\%, ASCEND-3: 58.9\%) and progression free survival (ASCEND-2: 5.7 months, ASCEND-3: 11.1 months).

\section{Trastuzumab}

Trastuzumab is a highly successful targeted monoclonal antibody therapy for HER2 positive cancers, but systemic administration can leave brain metastases and LMD as sanctuary sites [132-135]. Although pooled analysis of 17 patients with LMD from HER2 positive breast cancer suggested that trastuzumab may improve disease progression, randomized clinical trials are lacking [136]. In an ongoing Phase I and II trial, 34 adult patients were grouped into four cohorts of 3-6, with each cohort receiving varying dosages of IT trastuzumab twice a week for four weeks, then weekly for four weeks, and then every two weeks. Clinical, radiological, and CSF cytological responses are evaluated. Initial results from the Phase I study suggested increased efficacy at high dosages $(80 \mathrm{mg})$, with which the Phase II study is now progressing [137].

\section{Immunotherapy}

Immunotherapies have emerged as promising therapeutic options for several types of cancer including primary malignancies of the CNS and brain metastases. However, data are very limited on the utilization of these treatment modalities in patients with LMD [138]. There are a few studies reporting on either immune checkpoint blockade, intrathecal interleukin 2 (IL-2), or intrathecal tumor-infiltrating lymphocyte (TIL) therapies.

Checkpoint inhibitors such as ipilimumab and nivolumab, monoclonal antibodies that blocks CTLA-4 and PD-1, respectively, remain poorly studied in LMD, despite success and FDA approvals for a number of solid tumors. One case report documents a patient with melanoma-associated LMD who received WBRT followed by ipilimumab and survived for more than 18 months [139]. On the other hand, there is a case report of radiographic LMD mimicry in a separate melanoma patient treated with ipilimumab [140]. Regarding nivolumab, one study demonstrated improvement in neurological symptoms (auditory hallucinations) in an advanced NSCLC patient with LMD after treatment administration. Furthermore, the patient went on to exhibit a 7-month-progression-free survival [141]. Ultimately, further study of these agents is warranted.

Limited results are also reported for intrathecal IL-2 and TIL therapies. In a study of 42 patients with melanomaassociated LMD who were treated with intrathecal IL2, median survival was found to be 9.1 months (range $0.7-86.2$ ) with $16 \%$ of patients surviving more than 24 months [142]. These are certainly promising results, when 
compared to the normal median survival of 10 weeks in patients with metastatic melanoma LMD [143]. Additionally, a case report revealed radiographic disease stabilization in a patient with LMD from metastatic melanoma after administration of intrathecal autologous TILs in combination with intrathecal IL-2. Unfortunately, the regimen did not control the parenchymal brain metastases, which progressed 3 months following therapy [144]. Although such findings are encouraging, further well-designed randomized controlled studies are needed to evaluate the efficacy of immunotherapies in patients with LMD.

\section{FUTURE DIRECTIONS}

Understanding the biology of LMD has created outlets for new molecular diagnostic and therapeutic strategies. Making use of these techniques will provide mechanisms for earlier detection and more effective treatments.

\section{Diagnostics}

Looking for CSF biomarkers with high sensitivity can be more effective for early diagnosis of LMD as compared to CSF cytology and MRI. The latter both require a substantial level of disease progression in order to detect abnormalities, thereby contributing to delay in the treatment process. Treatment delay due to the insensitivity of current diagnostic methods can be improved through the analysis of CSF biomarkers. Testing for CSF VEGF has been shown to exhibit 75\% sensitivity, 97\% specificity, and 94\% negative predictive value in breast cancer LMD diagnosis [46]. Levels of LMD-derived cell-free DNA (cfDNA), which can be low in plasma due to the BBB, can also be analyzed in CSF to follow both progression and development of drug-resistance mutations, and thereby guide therapy [145]. For example, a recent study by Zhao et al. of seven patients with LMD secondary to EGFR-positive TKIresistent NSCLC patients found that a majority of patients were EGFR sensitive in CSF but not in plasma, possibly indicating poor TKI CSF penetration [146].

MicroRNA studies are able to detect abnormal levels of cancer-associated microRNAs in the CSF. In patients with metastatic brain and lung cancer, CSF miR$10 \mathrm{~b}$ and miR-21levels increased significantly compared to tumors in remission and other non-neoplastic conditions. Using longitudinal microRNA profiles, disease activity and treatment response can be monitored more effectively in patients with NSCLC metastases [147]. Furthermore, proteomic analysis of CSF can be used to identify peptides expressed in patients with LMD. The MALDI peptide analysis of CSF specifically is able to identify several proteins involved in the host-disease interaction, inflammation, and immunity typically seen in neoplastic processes [148].

Circulating tumor cells (CTC) in CSF provide another option for early detection of LMD. Using this method, molecular tumor cell markers, such as epithelial cell adhesion molecule (EPCAM), can be used to identify metastatic cells in the CSF for diagnosis. Additionally, CTC methods enable the capture of live tumor cells, which can contribute to the current understanding of LMD biology [149].

\section{Treatments}

Today, LMD is considered a fatal complication of cancer, as survival following diagnosis is devastatingly short. As science continues to reveal the underlying biology of LMD, treatments that reach the meninges and CSF while targeting the relevant molecular markers is essential to making advancements in diagnosis and treatment. Because most patients do not typically die solely from LMD, it is important for future therapies to address the systemic cancer in addition to the metastatic disease to improve survival. Progress is being made through the use of combination therapies, but there is still a large clinical unmet need for innovative treatments following diagnosis.

\section{Abbreviations}

ALK: Anaplastic lymphoma kinase; ALL: Acute lymphoblastic leukemia; Ara-C: Cytarabine; CEA: Carcinoembryonic antigen; $\mathrm{CI}$ : Confidence interval; $\mathrm{CNS}$ : Central nervous system; CSF: Cerebrospinal fluid; CTC: Circulating tumor cells; DHFR: Dihydrofolate reductase; EGFR: Epidermal Growth Factor Receptor; EPCAM: Epithelial cell adhesion molecule; HR: Hazard ratio; IL: Interleukin; KPS: Karnofsky Performance Score; LMD: Leptomeningeal disease; miR: micro-ribonucleic acid; MRI: Magnetic resonance imaging; MTX: Methotrexate; NHL: Non-Hodgkin's lymphoma; NSCLC: Non-smallcell lung cancer; RANO: Response Assessment in NeuroOncology group; TIL: Tumor-infiltrating lymphocyte; TKI: Tyrosine kinase inhibitor; TMZ: Temozolomide; VEGF: Vascular endothelial growth factor; WBRT: Whole brain radiation therapy.

\section{Author contributions}

Gautam Nayar: Literature review, writing, editing; Tiffany Ejikeme: Literature review, writing, editing; Pakawat Chonsathidkiet: Literature review, writing, editing; Aladine A. Elsamadicy: Literature review, writing; Kimberly L. Blackwell: Editing; Jeffrey M. Clarke: Editing; Shivanand P. Lad: Editing; Peter E. Fecci: Corresponding author, editing.

\section{CONFLICTS OF INTEREST}

None. 


\section{FUNDING}

No funding was received in support of this work.

\section{REFERENCES}

1. Youmans JR, Winn HR. (2011). Youmans neurological surgery. (Philadelphia, PA: Saunders/Elsevier,), pp. 4 v. (xci, 4206, xci p).

2. Clarke JL, Perez HR, Jacks LM, Panageas KS, Deangelis LM. Leptomeningeal metastases in the MRI era. Neurology. 2010; 74:1449-54. https://doi.org/10.1212/ WNL.0b013e3181dc1a69.

3. Hyun JW, Jeong IH, Joung A, Cho HJ, Kim SH, Kim HJ. Leptomeningeal metastasis: Clinical experience of 519 cases. Eur J Cancer. 2016; 56:107-14. https://doi. org/10.1016/j.ejca.2015.12.021.

4. Groves MD. Leptomeningeal disease. Neurosurg Clin $\mathrm{N}$ Am. 2011; 22:67-78, vii. https://doi.org/10.1016/j. nec.2010.08.006.

5. Chowdhary S, Chamberlain M. Leptomeningeal metastases: current concepts and management guidelines. J Natl Compr Canc Netw. 2005; 3:693-703.

6. Beauchesne P. Intrathecal chemotherapy for treatment of leptomeningeal dissemination of metastatic tumours. Lancet Oncol. 2010; 11:871-9. https://doi.org/10.1016/S14702045(10)70034-6.

7. Chamberlain M, Junck L, Brandsma D, Soffietti R, Ruda R, Raizer J, Boogerd W, Taillibert S, Groves MD, Rhun EL, Walker J, van den Bent M, Wen PY, et al. Leptomeningeal metastases: a RANO proposal for response criteria. Neuro Oncol. 2017; 19:484-492. https://doi.org/10.1093/neuonc/ now183.

8. Park JH, Kim YJ, Lee JO, Lee KW, Kim JH, Bang SM, Chung JH, Kim JS, Lee JS. Clinical outcomes of leptomeningeal metastasis in patients with non-small cell lung cancer in the modern chemotherapy era. Lung Cancer. 2012; 76:387-92. https://doi.org/10.1016/j. lungcan.2011.11.022.

9. Ozdemir Y, Yildirim BA, Topkan E. Whole brain radiotherapy in management of non-small-cell lung carcinoma associated leptomeningeal carcinomatosis: evaluation of prognostic factors. J Neurooncol. 2016; 129:329-35. https://doi.org/10.1007/s11060-016-2179-9.

10. Lee DW, Lee KH, Kim JW, Keam B. Molecular Targeted Therapies for the Treatment of Leptomeningeal Carcinomatosis: Current Evidence and Future Directions. Int J Mol Sci. 2016; 17. https://doi.org/10.3390/ ijms 17071074 .

11. Smalley KS, Fedorenko IV, Kenchappa RS, Sahebjam S, Forsyth PA. Managing leptomeningeal melanoma metastases in the era of immune and targeted therapy. Int J Cancer. 2016; 139:1195-201. https://doi.org/10.1002/ ijc. 30147 .
12. Chamberlain MC. Leptomeningeal metastasis. Curr Opin Neurol. 2009; 22:665-74. https://doi.org/10.1097/ WCO.0b013e3283322a92.

13. Grah JJ, Katalinic D, Stern-Padovan R, Paladino J, Santek F, Juretic A, Zarkovic K, Plestina S, Supe M. Leptomeningeal and intramedullary metastases of glioblastoma multiforme in a patient reoperated during adjuvant radiochemotherapy. World J Surg Oncol. 2013; 11:55. https://doi.org/10.1186/1477-7819-11-55.

14. Gani C, Muller AC, Eckert F, Schroeder C, Bender B, Pantazis G, Bamberg M, Berger B. Outcome after whole brain radiotherapy alone in intracranial leptomeningeal carcinomatosis from solid tumors. Strahlenther Onkol. 2012; 188:148-53. https://doi.org/10.1007/s00066-011-0025-8.

15. Leal T, Chang JE, Mehta M, Robins HI. Leptomeningeal Metastasis: Challenges in Diagnosis and Treatment. Curr Cancer Ther Rev. 2011; 7:319-27. https://doi. org/10.2174/157339411797642597.

16. Gainor JF, Ou SH, Logan J, Borges LF, Shaw AT. The central nervous system as a sanctuary site in ALK-positive non-small-cell lung cancer. J Thorac Oncol. 2013; 8:1570-3. https://doi.org/10.1097/JTO.0000000000000029.

17. Mack F, Baumert BG, Schafer N, Hattingen E, Scheffler B, Herrlinger U, Glas M. Therapy of leptomeningeal metastasis in solid tumors. Cancer Treat Rev. 2016; 43:83-91. https:// doi.org/10.1016/j.ctrv.2015.12.004.

18. Kaplan JG, DeSouza TG, Farkash A, Shafran B, Pack D, Rehman F, Fuks J, Portenoy R. Leptomeningeal metastases: comparison of clinical features and laboratory data of solid tumors, lymphomas and leukemias. J Neurooncol. 1990; 9:225-9.

19. Jaeckle KA. Neoplastic meningitis from systemic malignancies: diagnosis, prognosis and treatment. Semin Oncol. 2006; 33:312-23. https://doi.org/10.1053/j. seminoncol.2006.04.016.

20. Le Rhun E, Taillibert S, Chamberlain MC. Carcinomatous meningitis: Leptomeningeal metastases in solid tumors. Surg Neurol Int. 2013; 4:S265-88. https://doi. org/10.4103/2152-7806.111304.

21. Chamberlain M, Soffietti R, Raizer J, Ruda R, Brandsma D, Boogerd W, Taillibert S, Groves MD, Le Rhun E, Junck L, van den Bent M, Wen PY, Jaeckle KA. Leptomeningeal metastasis: a Response Assessment in Neuro-Oncology critical review of endpoints and response criteria of published randomized clinical trials. Neuro Oncol. 2014; 16:1176-85. https://doi.org/10.1093/neuonc/ nou089.

22. Chamberlain MC. Leptomeningeal metastasis. Semin Neurol. 2010; 30:236-44. https://doi. org/10.1055/s-0030-1255220.

23. Chamberlain MC. Neoplastic meningitis. Oncologist. 2008; 13:967-77. https://doi.org/10.1634/theoncologist.2008-0138.

24. Glass JP, Melamed M, Chernik NL, Posner JB. Malignant cells in cerebrospinal fluid (CSF): the meaning of a positive CSF cytology. Neurology. 1979; 29:1369-75. 
25. Glantz MJ, Cole BF, Glantz LK, Cobb J, Mills P, Lekos A, Walters BC, Recht LD. Cerebrospinal fluid cytology in patients with cancer: minimizing false-negative results. Cancer. 1998; 82:733-9.

26. Gleissner B, Chamberlain MC. Neoplastic meningitis. Lancet Neurol. 2006; 5:443-52. https://doi.org/10.1016/ S1474-4422(06)70443-4.

27. van Oostenbrugge RJ, Hopman AH, Arends JW, Ramaekers FC, Twijnstra A. Treatment of leptomeningeal metastases evaluated by interphase cytogenetics. J Clin Oncol. 2000; 18:2053-8. https://doi.org/10.1200/ jco.2000.18.10.2053.

28. Shin SY, Lee ST, Kim HJ, Oh YL, Kim SJ, Kim WS, Kim SH. Usefulness of Flow Cytometric Analysis for Detecting Leptomeningeal Diseases in Non-Hodgkin Lymphoma. Ann Lab Med. 2016; 36:209-14. https://doi. org/10.3343/alm.2016.36.3.209.

29. Chughtai B, Sedrakyan A, Isaacs A, Lee R, Te A, Kaplan S. Long term safety of sacral nerve modulation in medicare beneficiaries. Neurourol Urodyn. 2015; 34:659-63. https:// doi.org/10.1002/nau.22618.

30. Le Rhun E, Kramar A, Salingue S, Girot M, Rodrigues I, Mailliez A, Zairi F, Bakhache E, Robin YM, Taillibert S, Dubois F, Bonneterre J, Chamberlain MC. CSF CA 15-3 in breast cancer-related leptomeningeal metastases. J Neurooncol. 2014; 117:117-24. https://doi.org/10.1007/ s11060-014-1361-1.

31. Nakagawa H, Kubo S, Murasawa A, Nakajima S, Nakajima Y, Izumoto S, Hayakawa T. Measurements of CSF biochemical tumor markers in patients with meningeal carcinomatosis and brain tumors. J Neurooncol. 1992; 12:111-20.

32. Kang SJ, Kim KS, Ha YS, Huh SY, Lee JH, Kim JK, Kim MJ. Diagnostic value of cerebrospinal fluid level of carcinoembryonic antigen in patients with leptomeningeal carcinomatous metastasis. J Clin Neurol. 2010; 6:33-7. https://doi.org/10.3988/jcn.2010.6.1.33.

33. Kesari S, Batchelor TT. Leptomeningeal metastases. Neurol Clin. 2003; 21:25-66.

34. Jacobi C, Reiber H, Felgenhauer K. The clinical relevance of locally produced carcinoembryonic antigen in cerebrospinal fluid. J Neurol. 1986; 233:358-61.

35. Weston CL, Glantz MJ, Connor JR. Detection of cancer cells in the cerebrospinal fluid: current methods and future directions. Fluids Barriers CNS. 2011; 8:14. https://doi. org/10.1186/2045-8118-8-14

36. Chamberlain MC. Comprehensive neuraxis imaging in leptomeningeal metastasis: a retrospective case series. CNS Oncol. 2013; 2:121-8. https://doi.org/10.2217/cns.12.45.

37. Chamberlain MC, Sandy AD, Press GA. Leptomeningeal metastasis: a comparison of gadolinium-enhanced MR and contrast-enhanced CT of the brain. Neurology. 1990; 40:435-8.

38. Collie DA, Brush JP, Lammie GA, Grant R, Kunkler I, Leonard R, Gregor A, Sellar RJ. Imaging features of leptomeningeal metastases. Clin Radiol. 1999; 54:765-71.
39. Freilich RJ, Krol G, DeAngelis LM. Neuroimaging and cerebrospinal fluid cytology in the diagnosis of leptomeningeal metastasis. Ann Neurol. 1995; 38:51-7. https://doi.org/10.1002/ana.410380111.

40. Schumacher DJ, Tien RD, Friedman H. Gadolinium enhancement of the leptomeninges caused by hydrocephalus: a potential mimic of leptomeningeal metastasis. AJNR Am J Neuroradiol. 1994; 15:639-41.

41. Chamberlain MC, Kormanik PA. Prognostic significance of 111indium-DTPA CSF flow studies in leptomeningeal metastases. Neurology. 1996; 46:1674-7.

42. Mason WP, Yeh SD, DeAngelis LM. 111Indiumdiethylenetriamine pentaacetic acid cerebrospinal fluid flow studies predict distribution of intrathecally administered chemotherapy and outcome in patients with leptomeningeal metastases. Neurology. 1998; 50:438-44.

43. Chamberlain MC. Radioisotope CSF flow studies in leptomeningeal metastases. J Neurooncol. 1998; 38:135-40.

44. Grewal J, Saria MG, Kesari S. Novel approaches to treating leptomeningeal metastases. J Neurooncol. 2012; 106:225-34. https://doi.org/10.1007/s11060-011-0686-2.

45. Groves MD. The pathogenesis of neoplastic meningitis. Curr Oncol Rep. 2003; 5:15-23.

46. Groves MD, Hess KR, Puduvalli VK, Colman H, Conrad CA, Gilbert MR, Weinberg J, Cristofanilli M, Yung WK, Liu TJ. Biomarkers of disease: cerebrospinal fluid vascular endothelial growth factor (VEGF) and stromal cell derived factor (SDF)-1 levels in patients with neoplastic meningitis (NM) due to breast cancer, lung cancer and melanoma. J Neurooncol. 2009; 94:229-34. https://doi.org/10.1007/s11060-009-9819-2.

47. Lee TH, Avraham HK, Jiang S, Avraham S. Vascular endothelial growth factor modulates the transendothelial migration of MDA-MB-231 breast cancer cells through regulation of brain microvascular endothelial cell permeability. J Biol Chem. 2003; 278:5277-84. https://doi. org/10.1074/jbc.M210063200.

48. Stockhammer G, Poewe W, Burgstaller S, Deisenhammer F, Muigg A, Kiechl S, Schmutzhard E, Maier H, Felber S, Schumacher P, Gunsilius E, Gastl G. Vascular endothelial growth factor in CSF: a biological marker for carcinomatous meningitis. Neurology. 2000; 54:1670-6.

49. Kadoch C, Treseler P, Rubenstein JL. Molecular pathogenesis of primary central nervous system lymphoma. Neurosurg Focus. 2006; 21:E1.

50. Lee BC, Lee TH, Avraham S, Avraham HK. Involvement of the chemokine receptor CXCR4 and its ligand stromal cell-derived factor 1alpha in breast cancer cell migration through human brain microvascular endothelial cells. Mol Cancer Res. 2004; 2:327-38.

51. Singh S, Nannuru KC, Sadanandam A, Varney ML, Singh RK. CXCR1 and CXCR2 enhances human melanoma tumourigenesis, growth and invasion. Br J Cancer. 2009; 100:1638-46. https://doi.org/10.1038/sj.bjc.6605055.

52. Rudnicka H, Niwinska A, Murawska M. Breast cancer leptomeningeal metastasis - the role of multimodality 
treatment. J Neurooncol. 2007; 84:57-62. https://doi. org/10.1007/s11060-007-9340-4.

53. Wasserstrom WR, Glass JP, Posner JB. Diagnosis and treatment of leptomeningeal metastases from solid tumors: experience with 90 patients. Cancer. 1982; 49:759-72.

54. Wu YL, Zhou L, Lu Y. Intrathecal chemotherapy as a treatment for leptomeningeal metastasis of non-small cell lung cancer: A pooled analysis. Oncol Lett. 2016; 12: 1301-14. https://doi.org/10.3892/ol.2016.4783.

55. Riess JW, Nagpal S, Iv M, Zeineh M, Gubens MA, Ramchandran K, Neal JW, Wakelee HA. Prolonged survival of patients with non-small-cell lung cancer with leptomeningeal carcinomatosis in the modern treatment era. Clin Lung Cancer. 2014; 15:202-6. https://doi. org/10.1016/j.cllc.2013.12.009.

56. Morris PG, Reiner AS, Szenberg OR, Clarke JL, Panageas KS, Perez HR, Kris MG, Chan TA, DeAngelis LM, Omuro AM. Leptomeningeal metastasis from non-small cell lung cancer: survival and the impact of whole brain radiotherapy. J Thorac Oncol. 2012; 7:382-5. https://doi.org/10.1097/JTO.0b013e3182398e4f.

57. Mix M, Elmarzouky R, O’Connor T, Plunkett R, Prasad D. Clinical outcomes in patients with brain metastases from breast cancer treated with single-session radiosurgery or whole brain radiotherapy. J Neurosurg. 2016; 125:26-30. https://doi.org/10.3171/2016.7.GKS161541.

58. Bruna J, Simo M, Velasco R. Leptomeningeal metastases. Curr Treat Options Neurol. 2012; 14:402-15. https://doi. org/10.1007/s11940-012-0182-9.

59. Chamberlain MC, Kormanik P. Carcinoma meningitis secondary to non-small cell lung cancer: combined modality therapy. Arch Neurol. 1998; 55:506-12.

60. Remon J, Le Rhun E, Besse B. Leptomeningeal carcinomatosis in non-small cell lung cancer patients: A continuing challenge in the personalized treatment era. Cancer Treat Rev. 2017; 53:128-37. https://doi. org/10.1016/j.ctrv.2016.12.006.

61. Glantz MJ, Jaeckle KA, Chamberlain MC, Phuphanich S, Recht L, Swinnen LJ, Maria B, LaFollette S, Schumann GB, Cole BF, Howell SB. A randomized controlled trial comparing intrathecal sustained-release cytarabine (DepoCyt) to intrathecal methotrexate in patients with neoplastic meningitis from solid tumors. Clin Cancer Res. 1999; 5:3394-402.

62. Hoffmann AL, Buhk JH, Strik H. Neoplastic meningitis from breast cancer: feasibility and activity of long-term intrathecal liposomal Ara-C combined with dose-dense temozolomide. Anticancer Res. 2009; 29:5191-5.

63. Stemmler HJ, Mengele K, Schmitt M, Harbeck N, Laessig D, Herrmann KA, Schaffer P, Heinemann V. Intrathecal trastuzumab (Herceptin) and methotrexate for meningeal carcinomatosis in HER2-overexpressing metastatic breast cancer: a case report. Anticancer Drugs. 2008; 19:832-6. https://doi.org/10.1097/CAD.0b013e32830b58b0.
64. Lu NT, Raizer J, Gabor EP, Liu NM, Vu JQ, Slamon DJ, Barstis JL. Intrathecal trastuzumab: immunotherapy improves the prognosis of leptomeningeal metastases in HER-2+ breast cancer patient. J Immunother Cancer. 2015; 3:41. https://doi.org/10.1186/s40425-015-0084-y.

65. Park WY, Kim HJ, Kim K, Bae SB, Lee N, Lee KT, Won JH, Park HS, Lee SC. Intrathecal Trastuzumab Treatment in Patients with Breast Cancer and Leptomeningeal Carcinomatosis. Cancer Res Treat. 2016; 48:843-7. https:// doi.org/10.4143/crt.2014.234.

66. Bousquet $\mathrm{G}$, Darrouzain F, de Bazelaire C, Ternant D, Barranger E, Winterman S, Madelaine-Chambin I, Thiebaut JB, Polivka M, Paintaud G, Culine S, Janin A. Intrathecal Trastuzumab Halts Progression of CNS Metastases in Breast Cancer. J Clin Oncol. 2016; 34: e151-5. https://doi.org/10.1200/JCO.2012.44.8894.

67. Hitchins RN, Bell DR, Woods RL, Levi JA. A prospective randomized trial of single-agent versus combination chemotherapy in meningeal carcinomatosis. J Clin Oncol. 1987; 5:1655-62. https://doi.org/10.1200/ JCO.1987.5.10.1655.

68. Zoghi B, Elledge R. Endocrine Therapy for Leptomeningeal Metastases from ER-Positive Breast Cancer: Case Report and a Review of the Literature. Breast J. 2016; 22:218-23. https://doi.org/10.1111/tbj.12554.

69. Siegal T. Leptomeningeal metastases: rationale for systemic chemotherapy or what is the role of intra-CSFchemotherapy? J Neurooncol. 1998; 38:151-7.

70. Grant R, Naylor B, Greenberg HS, Junck L. Clinical outcome in aggressively treated meningeal carcinomatosis. Arch Neurol. 1994; 51:457-61.

71. Glantz MJ, Cole BF, Recht L, Akerley W, Mills P, Saris S, Hochberg F, Calabresi P, Egorin MJ. High-dose intravenous methotrexate for patients with nonleukemic leptomeningeal cancer: is intrathecal chemotherapy necessary? J Clin Oncol. 1998; 16:1561-7. https://doi.org/10.1200/JCO.1998.16.4.1561.

72. Hess JA, Khasawneh MK. Cancer metabolism and oxidative stress: Insights into carcinogenesis and chemotherapy via the non-dihydrofolate reductase effects of methotrexate. BBA Clin. 2015; 3:152-61. https://doi.org/10.1016/j. bbacli.2015.01.006.

73. Cole PD, Kamen BA, Gorlick R, Banerjee D, Smith AK, Magill E, Bertino JR. Effects of overexpression of gammaGlutamyl hydrolase on methotrexate metabolism and resistance. Cancer Res. 2001; 61:4599-604.

74. Liu DJ, Fu XL, Liu W, Zheng LY, Zhang JF, Huo YM, Li J, Hua R, Liu Q, Sun YW. Clinicopathological, treatment, and prognosis study of 43 gastric neuroendocrine carcinomas. World J Gastroenterol. 2017; 23:516-24. https://doi. org/10.3748/wjg.v23.i3.516.

75. McQuade RM, Stojanovska V, Bornstein JC, Nurgali K. Colorectal Cancer Chemotherapy: The Evolution of Treatment and New Approaches. Curr Med Chem. 2017; 24(15):1537-1557. http://doi.org/10.2174/0929867324666 170111152436. 
76. Aitelhaj M, Lkhoyaali S, Rais G, Boutayeb S, Errihani H. First line chemotherapy plus trastuzumab in metastatic breast cancer HER2 positive - Observational institutional study. Pan Afr Med J. 2016; 24:324. https://doi. org/10.11604/pamj.2016.24.324.4058.

77. Ekenel M, Hormigo AM, Peak S, Deangelis LM, Abrey LE. Capecitabine therapy of central nervous system metastases from breast cancer. J Neurooncol. 2007; 85:223-7. https:// doi.org/10.1007/s11060-007-9409-0.

78. Giglio P, Tremont-Lukats IW, Groves MD. Response of neoplastic meningitis from solid tumors to oral capecitabine. J Neurooncol. 2003; 65:167-72.

79. Tham YL, Hinckley L, Teh BS, Elledge R. Long-term clinical response in leptomeningeal metastases from breast cancer treated with capecitabine monotherapy: a case report. Clin Breast Cancer. 2006; 7:164-6. https://doi.org/10.3816/ CBC.2006.n.028.

80. Stupp R, Mason WP, van den Bent MJ, Weller M, Fisher B, Taphoorn MJ, Belanger K, Brandes AA, Marosi C, Bogdahn U, Curschmann J, Janzer RC, Ludwin SK, et al. Radiotherapy plus concomitant and adjuvant temozolomide for glioblastoma. N Engl J Med. 2005; 352:987-96. https:// doi.org/10.1056/NEJMoa043330.

81. Stupp R, Taillibert S, Kanner AA, Kesari S, Steinberg DM, Toms SA, Taylor LP, Lieberman F, Silvani A, Fink KL, Barnett GH, Zhu JJ, Henson JW, et al. Maintenance Therapy With Tumor-Treating Fields Plus Temozolomide vs Temozolomide Alone for Glioblastoma: A Randomized Clinical Trial. JAMA. 2015; 314:2535-43. https://doi. org/10.1001/jama.2015.16669.

82. Broniscer A, Chintagumpala M, Fouladi M, Krasin MJ, Kocak M, Bowers DC, Iacono LC, Merchant TE, Stewart CF, Houghton PJ, Kun LE, Ledet D, Gajjar A. Temozolomide after radiotherapy for newly diagnosed highgrade glioma and unfavorable low-grade glioma in children. J Neurooncol. 2006; 76:313-9. https://doi.org/10.1007/ s11060-005-7409-5.

83. Hansen N, Wittig A, Hense J, Kastrup O, Gizewski ER, Van de Nes JA. Long survival of primary diffuse leptomeningeal gliomatosis following radiotherapy and temozolomide: case report and literature review. Eur J Med Res. 2011; 16:415-9.

84. Reddy K, Gaspar LE, Kavanagh BD, Chen C. Hypofractionated intensity-modulated radiotherapy with temozolomide chemotherapy may alter the patterns of failure in patients with glioblastoma multiforme. J Med Imaging Radiat Oncol. 2014; 58:714-21. https://doi. org/10.1111/1754-9485.12185.

85. Bhatia R, Roncaroli F, Thomas P, Cheah SL, Mehta A, Glaser M, Ulbricht C. A case of primary leptomeningeal gliomatosis confined to the spinal cord. J Neurooncol. 2010; 98:125-9. https://doi.org/10.1007/s11060-009-0050-y.

86. Okita Y, Nonaka M, Umehara T, Kanemura Y, Kodama Y, Mano M, Nakajima S. Efficacy of temozolomide and bevacizumab for the treatment of leptomeningeal dissemination of recurrent glioblastoma: A case report. Oncol Lett. 2015; 9:1885-8. https://doi.org/10.3892/ ol.2015.2940.

87. Thomson N, Pacak K, Schmidt MH, Palmer CA, Salzman KL, Champine M, Schiffman JD, Cohen AL. Leptomeningeal dissemination of a low-grade lumbar paraganglioma: case report. J Neurosurg Spine. 2017: 1-6. https://doi.org/10.3171/2016.10.SPINE16948.

88. Lombardi G, Zustovich F, Della Puppa A, Borgato L, Orvieto E, Manara R, Cecchin D, Berti F, Farina P, Gardiman MP, Scienza R, Zagonel V. Cisplatin and temozolomide combination in the treatment of leptomeningeal carcinomatosis from ethmoid sinus intestinal-type adenocarcinoma. J Neurooncol. 2011; 104:381-6. https://doi.org/10.1007/s11060010-0484-2.

89. Lukas RV, Mata-Machado NA, Nicholas MK, Salgia R, Antic T, Villaflor VM. Leptomeningeal carcinomatosis in esophageal cancer: a case series and systematic review of the literature. Dis Esophagus. 2015; 28:772-81. https://doi. org/10.1111/dote. 12276 .

90. Ku GY, Krol G, Ilson DH. Successful treatment of leptomeningeal disease in colorectal cancer with a regimen of bevacizumab, temozolomide, and irinotecan. J Clin Oncol. 2007; 25:e14-6. https://doi.org/10.1200/ JCO.2006.10.3317.

91. Zauderer M, Krug LM, Pietanza MC, O'Rourke D. Leptomeningeal metastases from small cell lung cancer responsive to temozolomide therapy. J Thorac Oncol. 2010; 5:1716-7. https://doi.org/10.1097/JTO.0b013e3181f1cc32.

92. Subbiah V, Wolff JE. Rapid response to therapy of neurocutaneous melanosis with leptomeningeal melanoma. Pediatr Blood Cancer. 2010; 54:180-1. https://doi. org/10.1002/pbc.22279.

93. Hottinger AF, Favet L, Pache JC, Martin JB, Dietrich PY. Delayed but Complete Response following Oral Temozolomide Treatment in Melanoma Leptomeningeal Carcinomatosis. Case Rep Oncol. 2011; 4:211-5. https:// doi.org/10.1159/000327699.

94. Raizer JJ, Hwu WJ, Panageas KS, Wilton A, Baldwin DE, Bailey E, von Althann C, Lamb LA, Alvarado G, Bilsky MH, Gutin PH. Brain and leptomeningeal metastases from cutaneous melanoma: survival outcomes based on clinical features. Neuro Oncol. 2008; 10:199-207. https:// doi.org/10.1215/15228517-2007-058.

95. Segura PP, Gil M, Balana C, Chacon I, Langa JM, Martin M, Bruna J. Phase II trial of temozolomide for leptomeningeal metastases in patients with solid tumors. J Neurooncol. 2012; 109:137-42. https://doi.org/10.1007/ s11060-012-0879-3.

96. Kumthekar P, Grimm SA, Avram MJ, Kaklamani V, Helenowski I, Rademaker A, Cianfrocca M, Gradishar W, Patel J, Mulcahy M, McCarthy K, Raizer JJ. Pharmacokinetics and efficacy of pemetrexed in patients with brain or leptomeningeal metastases. J Neurooncol. 
2013; 112:247-55. https://doi.org/10.1007/s11060-0131055-0.

97. Niyikiza C, Baker SD, Seitz DE, Walling JM, Nelson K, Rusthoven JJ, Stabler SP, Paoletti P, Calvert AH, Allen RH. Homocysteine and methylmalonic acid: markers to predict and avoid toxicity from pemetrexed therapy. Mol Cancer Ther. 2002; 1:545-52.

98. Sun JM, Nam MH, Chung JY, Im B, Lee SY, Suh YL, Ahn JS, Park K, Ahn MJ. Safety and pharmacokinetics of intrathecal administration of pemetrexed in rats. Cancer Chemother Pharmacol. 2011; 68:531-8. https://doi. org/10.1007/s00280-010-1522-7.

99. Reijneveld JC, Brandsma D, Boogerd W, Bonfrer JG, Kalmijn S, Voest EE, Geurts-Moespot A, Visser MC, Taphoorn MJ. CSF levels of angiogenesis-related proteins in patients with leptomeningeal metastases. Neurology. 2005; 65:1120-2. https://doi.org/10.1212/01. wnl.0000178981.39984.c2.

100. Herrlinger U, Wiendl $H$, Renninger $M$, Forschler $H$, Dichgans J, Weller M. Vascular endothelial growth factor (VEGF) in leptomeningeal metastasis: diagnostic and prognostic value. Br J Cancer. 2004; 91:219-24. https://doi. org/10.1038/sj.bjc.6601953.

101. Wu PF, Lin CH, Kuo CH, Chen WW, Yeh DC, Liao HW, Huang SM, Cheng AL, Lu YS. A pilot study of bevacizumab combined with etoposide and cisplatin in breast cancer patients with leptomeningeal carcinomatosis. BMC Cancer. 2015; 15:299. https://doi.org/10.1186/s12885-015-1290-1.

102. Chen IC, Lin CH, Jan IS, Cheng AL, Lu YS. Bevacizumab might potentiate the chemotherapeutic effect in breast cancer patients with leptomeningeal carcinomatosis. J Formos Med Assoc. 2016; 115:243-8. https://doi. org/10.1016/j.jfma.2015.03.005.

103. Sandler A, Gray R, Perry MC, Brahmer J, Schiller JH, Dowlati A, Lilenbaum R, Johnson DH. Paclitaxelcarboplatin alone or with bevacizumab for non-small-cell lung cancer. N Engl J Med. 2006; 355:2542-50. https://doi. org/10.1056/NEJMoa061884.

104. Ariyasu R, Horiike A, Koyama J, Saiki M, Sonoda T, Kawashima Y, Takano N, Oguri T, Nishikawa S, Kitazono S, Yanagitani N, Ohyanagi F, Nishio M. Efficacy of bevacizumab and erlotinib combination for leptomeningeal carcinomatosis after failure of erlotinib. Anticancer Drugs. 2017; 28:565-567. https://doi. org/10.1097/CAD.0000000000000489.

105. Socinski MA, Langer CJ, Huang JE, Kolb MM, Compton P, Wang L, Akerley W. Safety of bevacizumab in patients with non-small-cell lung cancer and brain metastases. J Clin Oncol. 2009; 27:5255-61. https://doi.org/10.1200/ JCO.2009.22.0616

106. Kleinschmidt-DeMasters BK, Damek DM. The imaging and neuropathological effects of Bevacizumab (Avastin) in patients with leptomeningeal carcinomatosis. J Neurooncol. 2010; 96:375-84. https://doi.org/10.1007/s11060-0099969-2.
107. Mathews MS, Linskey ME, Hasso AN, Fruehauf JP. The effect of bevacizumab (Avastin) on neuroimaging of brain metastases. Surg Neurol. 2008; 70:649-52; discussion 53. https://doi.org/10.1016/j.surneu.2007.06.029.

108. Maemondo M, Inoue A, Kobayashi K, Sugawara S, Oizumi S, Isobe H, Gemma A, Harada M, Yoshizawa H, Kinoshita I, Fujita Y, Okinaga S, Hirano H, et al. Gefitinib or chemotherapy for non-small-cell lung cancer with mutated EGFR. N Engl J Med. 2010; 362:2380-8. https:// doi.org/10.1056/NEJMoa0909530.

109. Thomas A, Rajan A, Giaccone G. Tyrosine kinase inhibitors in lung cancer. Hematol Oncol Clin North Am. 2012; 26:589-605, viii. https://doi.org/10.1016/j.hoc.2012.02.001.

110. Liao BC, Lee JH, Lin CC, Chen YF, Chang CH, Ho CC, Shih JY, Yu CJ, Yang JC. Epidermal Growth Factor Receptor Tyrosine Kinase Inhibitors for Non-Small-Cell Lung Cancer Patients with Leptomeningeal Carcinomatosis. J Thorac Oncol. 2015; 10:1754-61. https://doi.org/10.1097/ JTO.0000000000000669.

111. Lee E, Keam B, Kim DW, Kim TM, Lee SH, Chung DH, Heo DS. Erlotinib versus gefitinib for control of leptomeningeal carcinomatosis in non-small-cell lung cancer. J Thorac Oncol. 2013; 8:1069-74. https://doi. org/10.1097/JTO.0b013e318294c8e8.

112. Yi HG, Kim HJ, Kim YJ, Han SW, Oh DY, Lee SH, Kim DW, Im SA, Kim TY, Kim CS, Heo DS, Bang YJ. Epidermal growth factor receptor (EGFR) tyrosine kinase inhibitors (TKIs) are effective for leptomeningeal metastasis from non-small cell lung cancer patients with sensitive EGFR mutation or other predictive factors of good response for EGFR TKI. Lung Cancer. 2009; 65:80-4. https://doi. org/10.1016/j.lungcan.2008.10.016.

113. Togashi Y, Masago K, Masuda S, Mizuno T, Fukudo M, Ikemi Y, Sakamori Y, Nagai H, Kim YH, Katsura T, Mishima M. Cerebrospinal fluid concentration of gefitinib and erlotinib in patients with non-small cell lung cancer. Cancer Chemother Pharmacol. 2012; 70:399-405. https:// doi.org/10.1007/s00280-012-1929-4.

114. Jackman DM, Cioffredi LA, Jacobs L, Sharmeen F, Morse LK, Lucca J, Plotkin SR, Marcoux PJ, Rabin MS, Lynch TJ, Johnson BE, Kesari S. A phase I trial of high dose gefitinib for patients with leptomeningeal metastases from non-small cell lung cancer. Oncotarget. 2015; 6:4527-36. https://doi. org/10.18632/oncotarget.2886.

115. Kawamura T, Hata A, Takeshita J, Fujita S, Hayashi M, Tomii K, Katakami N. High-dose erlotinib for refractory leptomeningeal metastases after failure of standarddose EGFR-TKIs. Cancer Chemother Pharmacol. 2015; 75:1261-6. https://doi.org/10.1007/s00280-015-2759-y.

116. Hidalgo M, Siu LL, Nemunaitis J, Rizzo J, Hammond LA, Takimoto C, Eckhardt SG, Tolcher A, Britten CD, Denis L, Ferrante K, Von Hoff DD, Silberman S, et al. Phase I and pharmacologic study of OSI-774, an epidermal growth factor receptor tyrosine kinase inhibitor, in patients with advanced solid malignancies. J Clin Oncol. 2001; 19: 3267-79. https://doi.org/10.1200/JCO.2001.19.13.3267. 
117. How J, Mann J, Laczniak AN, Baggstrom MQ. Pulsatile Erlotinib in EGFR-Positive Non-Small-Cell Lung Cancer Patients With Leptomeningeal and Brain Metastases: Review of the Literature. Clin Lung Cancer. 2017; 18:354-363. https://doi.org/10.1016/j.cllc.2017.01.013.

118. Hoffknecht P, Tufman A, Wehler T, Pelzer T, Wiewrodt R, Schutz M, Serke M, Stohlmacher-Williams J, Marten A, Maria Huber R, Dickgreber NJ, Afatinib Compassionate Use Consortium. Efficacy of the irreversible ErbB family blocker afatinib in epidermal growth factor receptor (EGFR) tyrosine kinase inhibitor (TKI)-pretreated nonsmall-cell lung cancer patients with brain metastases or leptomeningeal disease. J Thorac Oncol. 2015; 10:156-63. https://doi.org/10.1097/JTO.0000000000000380.

119. Kawaguchi Y, Hanaoka J, Hayashi H, Mizusaki N, Iihara H, Itoh Y, Sugiyama T. Clinical Efficacy of Afatinib Treatment for a Patient with Leptomeningeal Carcinomatosis. Chemotherapy. 2016; 62:147-50. https:// doi.org/10.1159/000454727.

120. Nanjo S, Ebi H, Arai S, Takeuchi S, Yamada T, Mochizuki S, Okada Y, Nakada M, Murakami T, Yano S. High efficacy of third generation EGFR inhibitor AZD9291 in a leptomeningeal carcinomatosis model with EGFRmutant lung cancer cells. Oncotarget. 2016; 7:3847-56. https://doi.org/10.18632/oncotarget.6758.

121. Yang Z, Guo Q, Wang Y, Chen K, Zhang L, Cheng Z, Xu Y, Yin X, Bai Y, Rabbie S, Kim DW, Ahn MJ, Yang JC, et al. AZD3759, a BBB-penetrating EGFR inhibitor for the treatment of EGFR mutant NSCLC with CNS metastases. Sci Transl Med. 2016; 8:368ra172. https://doi.org/10.1126/ scitranslmed.aag0976.

122. Kwak EL, Bang YJ, Camidge DR, Shaw AT, Solomon B, Maki RG, Ou SH, Dezube BJ, Janne PA, Costa DB, VarellaGarcia M, Kim WH, Lynch TJ, et al. Anaplastic lymphoma kinase inhibition in non-small-cell lung cancer. N Engl J Med. 2010; 363:1693-703. https://doi.org/10.1056/ NEJMoa1006448.

123. Travis WD, Brambilla E, Noguchi M, Nicholson AG, Geisinger KR, Yatabe Y, Beer DG, Powell CA, Riely GJ, Van Schil PE, Garg K, Austin JH, Asamura H, et al. International Association for the Study of Lung Cancer/ American Thoracic Society/European Respiratory Society International Multidisciplinary Classification of Lung Adenocarcinoma. J Thorac Oncol. 2011; 6:244-85. https:// doi.org/10.1097/JTO.0b013e318206a221.

124. Riess JW, Nagpal S, Neal JW, Wakelee HA. A patient with anaplastic lymphoma kinase-positive non-small cell lung cancer with development of leptomeningeal carcinomatosis while on targeted treatment with crizotinib. J Natl Compr Canc Netw. 2013; 11:389-94.

125. Costa DB, Kobayashi S, Pandya SS, Yeo WL, Shen Z, Tan W, Wilner KD. CSF concentration of the anaplastic lymphoma kinase inhibitor crizotinib. J Clin Oncol. 2011; 29:e443-5. https://doi.org/10.1200/JCO.2010.34.1313.

126. Arrondeau J, Ammari S, Besse B, Soria JC. LDK378 compassionate use for treating carcinomatous meningitis in an ALK translocated non-small-cell lung cancer. J Thorac Oncol. 2014; 9:e62-3. https://doi.org/10.1097/ JTO.0000000000000174.

127. Ou SH, Sommers KR, Azada MC, Garon EB. Alectinib induces a durable ( $>15$ months) complete response in an ALK-positive non-small cell lung cancer patient who progressed on crizotinib with diffuse leptomeningeal carcinomatosis. Oncologist. 2015; 20:224-6. https://doi. org/10.1634/theoncologist.2014-0309.

128. Seto T, Kiura K, Nishio M, Nakagawa K, Maemondo M, Inoue A, Hida T, Yamamoto N, Yoshioka H, Harada M, Ohe Y, Nogami N, Takeuchi K, et al. CH5424802 (RO5424802) for patients with ALK-rearranged advanced non-small-cell lung cancer (AF-001JP study): a single-arm, open-label, phase 1-2 study. Lancet Oncol. 2013; 14:590-8. https://doi. org/10.1016/S1470-2045(13)70142-6.

129. Kim DW, Mehra R, Tan DS, Felip E, Chow LQ, Camidge DR, Vansteenkiste J, Sharma S, De Pas T, Riely GJ, Solomon BJ, Wolf J, Thomas M, et al. Activity and safety of ceritinib in patients with ALK-rearranged non-smallcell lung cancer (ASCEND-1): updated results from the multicentre, open-label, phase 1 trial. Lancet Oncol. 2016; 17:452-63. https://doi.org/10.1016/S1470-2045(15)00614-2.

130. Crino L, Ahn MJ, De Marinis F, Groen HJ, Wakelee H, Hida T, Mok T, Spigel D, Felip E, Nishio M, Scagliotti G, Branle F, Emeremni C, et al. Multicenter Phase II Study of Whole-Body and Intracranial Activity With Ceritinib in Patients With ALK-Rearranged Non-Small-Cell Lung Cancer Previously Treated With Chemotherapy and Crizotinib: Results From ASCEND-2. J Clin Oncol. 2016; 34:2866-73. https://doi.org/10.1200/JCO.2015.65.5936.

131. Facchinetti F, Tiseo M, Di Maio M, Graziano P, Bria E, Rossi G, Novello S. Tackling ALK in non-small cell lung cancer: the role of novel inhibitors. Transl Lung Cancer Res. 2016; 5:301-21. https://doi.org/10.21037/tlcr.2016.06.10.

132. Le XF, Pruefer F, Bast RC, Jr. HER2-targeting antibodies modulate the cyclin-dependent kinase inhibitor p27Kip1 via multiple signaling pathways. Cell Cycle. 2005; 4:87-95. https://doi.org/10.4161/cc.4.1.1360.

133. Kordbacheh T, Law WY, Smith IE. Sanctuary site leptomeningeal metastases in HER-2 positive breast cancer: A review in the era of trastuzumab. Breast. 2016; 26:54-8. https://doi.org/10.1016/j.breast.2015.11.005.

134. Morikawa A, Jordan L, Rozner R, Patil S, Boire A, Pentsova E, Seidman AD. Characteristics and Outcomes of Patients With Breast Cancer With Leptomeningeal Metastasis. Clin Breast Cancer. 2017; 17:23-8. https://doi.org/10.1016/j. clbc.2016.07.002.

135. Stemmler HJ, Schmitt M, Willems A, Bernhard H, Harbeck N, Heinemann V. Ratio of trastuzumab levels in serum and cerebrospinal fluid is altered in HER2-positive breast cancer patients with brain metastases and impairment of bloodbrain barrier. Anticancer Drugs. 2007; 18:23-8. https://doi. org/10.1097/01.cad.0000236313.50833.ee.

136. Zagouri F, Sergentanis TN, Bartsch R, Berghoff AS, Chrysikos D, de Azambuja E, Dimopoulos MA, Preusser M. 
Intrathecal administration of trastuzumab for the treatment of meningeal carcinomatosis in HER2-positive metastatic breast cancer: a systematic review and pooled analysis. Breast Cancer Res Treat. 2013; 139:13-22. https://doi. org/10.1007/s10549-013-2525-y.

137. Raizer J, Pentsova E, Omuro A, Lin N, Nayak L, Quant E, Kumthekar P. Phase I Trial of Intrathecal Trastuzumab in Her2 Positive Leptomeningeal Metastases. NeuroOncology. 2014; 16:v19-v. https://doi.org/10.1093/neuonc/ nou237.46.

138. Sahebjam S, Forsyth PA, Smalley KS, Tran ND. Experimental Treatments for Leptomeningeal Metastases From Solid Malignancies. Cancer Control. 2017; 24:42-6.

139. Bot I, Blank CU, Brandsma D. Clinical and radiological response of leptomeningeal melanoma after whole brain radiotherapy and ipilimumab. J Neurol. 2012; 259:1976-8. https://doi.org/10.1007/s00415-012-6488-4.

140. Ali S, Lee SK. Ipilimumab Therapy for Melanoma: A Mimic of Leptomeningeal Metastases. AJNR Am J Neuroradiol. 2015; 36:E69-70. https://doi.org/10.3174/ajnr.A4581.

141. Gion M, Remon J, Caramella C, Soria JC, Besse B. Symptomatic leptomeningeal metastasis improvement with nivolumab in advanced non-small cell lung cancer patient. Lung Cancer. 2017; 108:72-4. https://doi.org/10.1016/j. lungcan.2017.02.022.

142. Glitza IC, Rohlfs M, Bassett R, John I, Richard J, Iqbal M, Bernzen T, Gerber D, Lacey C, Diab A. IMCT-07 Therapeutic outcomes of intrathecal interleukin-2 in metastatic melanoma patients with leptomeningeal disease (LMD). Neuro-oncology. 2015; 17:v108-v.

143. Harstad L, Hess KR, Groves MD. Prognostic factors and outcomes in patients with leptomeningeal melanomatosis. Neuro Oncol. 2008; 10:1010-8. https://doi. org/10.1215/15228517-2008-062.

144. Glitza IC, Haymaker C, Bernatchez C, Vence L, Rohlfs M, Richard J, Lacey C, Mansaray R, Fulbright OJ, Ramachandran R, Toth C, Wardell S, Patel SP, et al.
Intrathecal Administration of Tumor-Infiltrating Lymphocytes Is Well Tolerated in a Patient with Leptomeningeal Disease from Metastatic Melanoma: A Case Report. Cancer Immunol Res. 2015; 3:1201-6. https:// doi.org/10.1158/2326-6066.CIR-15-0071.

145. Pentsova EI, Shah RH, Tang J, Boire A, You D, Briggs S, Omuro A, Lin X, Fleisher M, Grommes C, Panageas KS, Meng F, Selcuklu SD, et al. Evaluating Cancer of the Central Nervous System Through Next-Generation Sequencing of Cerebrospinal Fluid. J Clin Oncol. 2016; 34:2404-15. https://doi.org/10.1200/JCO.2016.66.6487.

146. Zhao J, Ye X, Xu Y, Chen M, Zhong W, Sun Y, Yang Z, Zhu G, Gu Y, Wang M. EGFR mutation status of paired cerebrospinal fluid and plasma samples in EGFR mutant non-small cell lung cancer with leptomeningeal metastases. Cancer Chemother Pharmacol. 2016; 78:1305-10. https:// doi.org/10.1007/s00280-016-3155-y.

147. Teplyuk NM, Mollenhauer B, Gabriely G, Giese A, Kim E, Smolsky M, Kim RY, Saria MG, Pastorino S, Kesari S, Krichevsky AM. MicroRNAs in cerebrospinal fluid identify glioblastoma and metastatic brain cancers and reflect disease activity. Neuro Oncol. 2012; 14:689-700. https:// doi.org/10.1093/neuonc/nos074.

148. Rompp A, Dekker L, Taban I, Jenster G, Boogerd W, Bonfrer H, Spengler B, Heeren R, Smitt PS, Luider TM. Identification of leptomeningeal metastasis-related proteins in cerebrospinal fluid of patients with breast cancer by a combination of MALDI-TOF, MALDI-FTICR and nanoLC-FTICR MS. Proteomics. 2007; 7:474-81. https:// doi.org/10.1002/pmic.200600719.

149. Patel AS, Allen JE, Dicker DT, Peters KL, Sheehan JM, Glantz MJ, El-Deiry WS. Identification and enumeration of circulating tumor cells in the cerebrospinal fluid of breast cancer patients with central nervous system metastases. Oncotarget. 2011; 2:752-60. https://doi.org/10.18632/ oncotarget.336. 